 \\ z Filologii Polskiej i Słowiańskiej
}

\author{
Roman Roszko \\ (Instytut Slawistyki Polskiej Akademii Nauk, Warszawa)
}

\section{Pamięci Profesor Violetty Koseskiej}

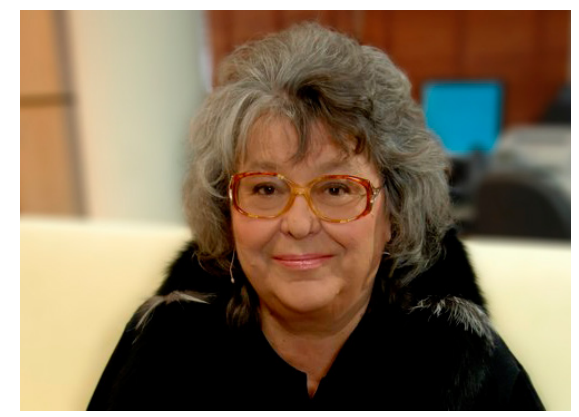

\section{PROFESOR DR HAB. VIOLETTA KOSESKA-TOSZEWA}

13 grudnia 1940 - 5 sierpnia 2017

Bułgarka! Wybitna uczona polska, językoznawczyni.

Zasłużona slawistka, bułgarystka, rusycystka.

Niezrównana organizatorka międzynarodowej współpracy naukowej.

Twórczyni uznanych w świecie teorii logiczno-lingwistycznych.

Niedościgniona mistrzyni i nauczycielka wielu slawistów.

Doctor honoris causa Bułgarskiej Akademii Nauk.

Autorka ponad pięciuset prac naukowych, tłumaczka, poliglotka.

This is an Open Access article distributed under the terms of the Creative Commons Attribution 3.0 PL License (creativecommons.org/licenses/by/3.0/pl/), which permits redistribution, commercial and non-commercial, provided that the article is properly cited. (c) The Author(s) 2018.

Publisher: Institute of Slavic Studies, Polish Academy of Sciences

[Wydawca: Instytut Slawistyki Polskiej Akademii Nauk] 
Teve mvsu kuris esi Dangwasu

Szwyskisi vardas tava.

Athayki tava karalistya.

Buki thava vala kayp dvngvy theyp szamyay.

Dvanv mvsu visu dzenv dvaki mvmvs nv

yr athlayski mvmvs mvsv kalthes

kayp yr mes athlyaydzame mvsv kalczyemvs.

Nyevyaski mvsv szalanv

ale mvs gyalbyaki nvagi visa piktha ${ }^{1}$.

Kiedy wracaliśmy z pogrzebu profesora Adama Weinsberga, a było to zimą 1992 roku, śp. Profesor Violetta Koseska powiedziała, że bardzo chciałaby, bym na jej pogrzebie zmówił modlitwę w starym języku litewskim. Skąd takie życzenie Profesor? Otóż na tym właśnie pogrzebie profesor Wojciech Smoczyński modlitwą Ojcze Nasz w starolitewskim wariancie żegnał profesora Adama Weinsberga. Jak wkrótce się zorientowałem, Profesor Koseska miała trudną do określenia słabość do języka litewskiego. Znała jego rolę w indoeuropeistyce. Przez pewien czas uczyła się na organizowanych w Uniwersytecie Warszawskim lektoratach języka litewskiego. Chyba jednak najbardziej zachwyciła się jego melodią, gdy bowiem odwoziłem Profesor z Instytutu Slawistyki PAN do domu, prosiła, bym włączał litewskie pieśni. Słuchała, lecz nigdy nie pytała, co jest ich treścią. Jednak gdy chciała raz jeszcze posłuchać konkretnej pieśni, zawsze potrafiła opisać jej treść. Po latach miejsce litewskich pieśni zajęły muzyka i śpiewy mongolskie (w tym buddyjskie). Profesor pasjonowała różnorodność głosów i wykonań. Potrafiła powtórzyć trudne dla Europejczyka brzmienia. Trzeba wyraźnie podkreślić, Profesor była uzdolniona muzycznie ${ }^{2}$, a szczególnie upodobała sobie śpiew. Śpiewała czysto i donośnie. Najpiękniej z profesorem Jordanem Penczewem na głosy. W roku 1987 po raz pierwszy usłyszałem, jak Profesor Koseska potrafi śpiewać. Byliśmy wówczas w Sofii. Po kilku dniach pracy nad koncepcją kolejnego tomu Gramatyki konfrontatywnej bułgarsko-polskiej profesor Dina Staniszewa zaprosiła mieszany polsko-bułgarski zespół do restauracji. Było tam kilka sal. W jednej młodzi

1 Za Lebedys, 1977, s. 36.

${ }^{2}$ Grała na skrzypcach oraz tańczyła w balecie. Nie ukończyła jednak szkoły muzycznej, do której uczęszczała aż do 17. roku życia. Śmierć matki zmieniła plany Profesor Koseskiej i jej ojca. 
ludzie bawili się przy muzyce dyskotekowej. Nam przypadła salka tuż obok. Hałas dochodzący zza ściany, nie powiem, przeszkadzał. Radosna Profesor Koseska zaczęła jednak śpiewać, przyłączył się do niej profesor Penczew. Śpiewali na dwa głosy, z każdą chwilą coraz donośniej. Wtem do naszej salki wkroczył kelner i po prostu przerwał śpiewy. Nieco zdziwieni popatrzyliśmy na niego, on zaś nieśmiało zapytał, czy może zostawić otwarte drzwi, a może nawet lepiej - rozsunąć ściankę odgradzającą nas od pozostałej przestrzeni restauracji. Profesor Penczew, zapytawszy o przyczynę takiej prośby, usłyszał wyjaśnienie, że goście z sąsiedniej sali - tak, z tej obok, gdzie jeszcze przed chwilą rozbrzmiewała muzyka dyskotekowa - chcą posłuchać śpiewów. Po chwili ściana została przesunięta, a w jej miejscu stali młodzi ludzie wsłuchujący się w śpiew Profesor Koseskiej i profesora Penczewa. Podziwiali w milczeniu, w przerwach nagradzali gromkimi oklaskami. Koncert musiał się kiedyś skończyć. Kelner ponownie rozgrodził salki. Jednak już muzyki młodzieżowej więcej tego wieczora nie słyszeliśmy.

Profesor Koseska miała wiele pasji. Była nią nie tylko muzyka (poważna, ludowa) czy śpiew (także operowy), ale i literatura, poezja, filozofia, psychologia... oraz astrologia. Jeszcze przed nastaniem epoki komputerów biurowych Profesor Koseska miała 8-bitowy komputer znanej wówczas firmy Atari, a w nim nie tylko gry (fakt, lubiła grać), lecz także napisany przez profesora Antoniego Mazurkiewicza (jej męża i największego życiowego przyjaciela) program do opracowywania horoskopów. Nie można pominąć faktu, że fabrycznie szaro-niebieskie atari miało wyraźny odcień mlecznej kawy. Kawy, którą Profesor lubiła pić i przypadkiem bezpiecznie wylewać na komputer. Powróćmy jednak do astrologii. Była ona wielką pasją Profesor Koseskiej (a może Davida Harklaya, taki bowiem pseudonim przyjęła). Wydała na ten temat wiele książek. Była gościem szeregu programów telewizyjnych i radiowych. Uważała, że astrologia nie jest magią, lecz nauką empiryczną opisującą zachowania człowieka pod wpływem kosmosu. W swych książkach poruszała zagadnienia tzw. pięciu znaków zodiaku każdego człowieka, zależności między znakiem zodiaku a odżywianiem. Horoskopy indywidualne i partnerskie również leżały w jej domenie. Profesor Koseska potrafiła przewidzieć wiele przyszłych zdarzeń, chyba największym jej proroctwem była konkretna data zakończenia wojny w Iraku. Zdolności jasnowidzenia mogła dziedziczyć po rodzinie ojca. Nieraz wspominała swoją babkę, która nauczyła ją śpiewać, tańczyć i cenić poezję. Pewnego dnia babka poprosiła, by szybciej zwolnić jej łazienkę, ponieważ chciałaby 
się przygotować do śmierci. Profesor Koseska, wówczas jeszcze jako mała Violetta, poszła jak zawsze do szkoły, lecz po niecałej godzinie wybiegła z lekcji, czuła bowiem, że babka umiera. Gdy zdyszana dobiegła do domu, babka już nie żyła.

Profesor Koseska była piątkową uczennicą i studentką. Twierdziła, że dobre oceny otrzymywała dzięki temu, że potrafiła trafnie przewidzieć pytania. Drocząc się z Profesor Koseską, mówiłem, że to nieprawda. Po prostu nie było takiego pytania, na które nie umiałaby śpiewająco odpowiedzieć. Profesor Koseska była profesjonalistką. Czymkolwiek się zainteresowała, musiała poznać rzecz w najdrobniejszych szczegółach.

Violetta Toszewa urodziła się w Sofii. O dniu każdych kolejnych urodzin - 13 grudnia - pamiętali wszyscy jej współpracownicy. Śmierć ukochanej babki i przedwczesna śmierć matki wpłynęły na losy przyszłej Profesor. Pod wpływem ojca zrezygnowała $z$ wymarzonych studiów muzycznych na rzecz rusycystyki. Zaczęła kształcić się w kierunku, który jej rodzinie nie był obcy. Zarówno matka, jak i ciotka były bułgarystkami, slawistkami. Profesor Koseska wielokrotnie wspominała bardzo przez siebie szanowaną nauczycielkę języka rosyjskiego, przybyłą z Rosji grafinię A.T. To ona perfekcyjnie nauczyła Profesor rosyjskiej mowy. Zdolności Profesor Koseskiej sprawiły, że szybko uzyskała stypendium naukowe „Christo Botew”, co pozwoliło jej usamodzielnić się finansowo. Obroniwszy pracę magisterską z zakresu dramaturgii, kończy studia filologiczne w Sofii - w mieście, w którym się urodziła, wychowała, o którym zawsze z pasją opowiadała. Wspomniana już grafini zaszczepiła w Profesor Koseskiej miłość do poezji symbolicznej. Postać i poezja Anny Achmatowej mogłyby stać się przedmiotem rozprawy doktorskiej Profesor, gdyby nie uwarunkowania polityczne. W Bułgarii był to temat zakazany. Wtedy wybawieniem dla samej Profesor okazał się goszczący w Bułgarii naukowiec z Polski, profesor Adam Koseski. Rzeczy tak się ułożyły, że w wyniku tej znajomości Profesor Koseska wyjechała do Polski. Okazało się, że również w Polsce jej wymarzony temat nie jest dobrze widziany. Dostała jednak wielką szansę. Została, jak się później okazało, ostatnią uczennicą-doktorantką profesora Zdzisława Stiebera. W roku 1970 uzyskała stopień doktora nauk humanistycznych. Sześć lat później pomyślnie przeszła proces habilitacyjny. W 1990 roku otrzymała tytuł profesora nauk humanistycznych. Była (współ)założycielem i redaktorem naukowym wielu czasopism i serii wydawniczych, członkiem Polskiego Towarzystwa Językoznawczego i honorowym członkiem Instytutu Języka Bułgarskiego BAN. 
Profesor Koseska została wielokrotnie wyróżniona wysokimi odznaczeniami państwowymi - polskimi i bułgarskimi: Krzyżem Kawalerskim Orderu Odrodzenia Polski, Krzyżem Oficerskim Orderu Odrodzenia Polski, najwyższym odznaczeniem naukowym Bułgarskiej Akademii Nauk - Złotą Odznaką im. Marina Drinowa ze Wstęgą oraz Złotą Odznaką Instytutu Języka Bułgarskiego im. Profesora Lubomira Andrejczina, a także medalami „100 lat Bułgarskiej Akademii Nauk” i „50 lat Slawistyki w Polskiej Akademii Nauk". W roku 2016 zostaje uhonorowana przez Bułgarską Akademię Nauk tytułem doktora honoris causa.

Profesor przez lata z powodzeniem kierowała Zespołem Lingwistyki Korpusowej i Semantyki, z którym uczestniczyła w wielu międzynarodowych projektach naukowych, w tym MONDILEX ${ }^{3}$ oraz CLARIN-PL („CLARIN-PL”, b.d.). Była inicjatorką i kierowniczką wielu tematów badawczych we współpracy międzynarodowej Instytutu Slawistyki Polskiej Akademii Nauk z Instytutem Języka Bułgarskiego Bułgarskiej Akademii Nauk, Instytutem Matematyki i Informatyki Bułgarskiej Akademii Nauk oraz z innymi jednostkami naukowymi spoza Bułgarii, w tym z uniwersytetami i akademiami w Chorwacji, Francji, Szwajcarii, Rosji, Słowacji, Słowenii, Stanach Zjednoczonych Ameryki i na Ukrainie.

Była współzałożycielką i wieloletnim redaktorem naczelnym wielu serii wydawniczych (w tym Studiów gramatycznych bułgarsko-polskich, Semantyki a konfrontacji językowej) oraz pism (takich jak „Slavia Meridionalis” (https:// ispan.waw.pl/journals/index.php/sm/issue/view/88) czy „Cognitive Studies | Études cognitives” (https://ispan.waw.pl/journals/index.php/cs-ec/index)) oraz kierownikiem Studiów Doktoranckich w Instytucie Slawistyki Polskiej Akademii Nauk - w Instytucie, z którym związała całe swe życie naukowe.

Największym dziełem Profesor Violetty Koseskiej była wielotomowa Gramatyka konfrontatywna bułgarsko-polska (1988-2009), publikowana w Bułgarii

${ }^{3}$ Lata 2008-2010. Siódmy europejski projekt ramowy (FP7) MONDILEX (Conceptual Modelling of Networking of Centres for High-Quality Research in Slavic Lexicography and Their Digital Resources). Główny cel projektu - stworzenie ogólnego schematu infrastruktury badawczej wspierającej badania leksykograficzne języków słowiańskich.

${ }^{4}$ Lata 2013-2016. Podstawowe zadanie Zespołu IS PAN - budowa wielojęzycznych baz pamięci tłumaczeniowych dla języków słowiańskich i bałtyckich o łącznej objętości blisko 17500000 słowoform: Polish-Bulgarian-Russian Parallel Corpus (Kisiel, Koseska-Toszewa, Kotsyba, Satoła-Staśkowiak, \& Sosnowski, 2016) oraz Polish-Lithuanian Parallel Corpus (D. Roszko \& Roszko, 2016). W ramach tego projektu przygotowano również podstawy anotacji semantycznej zasobów korpusowych (Koseska-Toszewa \& Roszko, 2015, 2016). 
(pierwsze cztery tomy) i w Polsce. Gramatyka liczy 9 tomów ${ }^{5}$. Pomysł na nowego typu gramatykę zrodził się w latach 70. minionego wieku w nieistniejącej już Pracowni Języków Południowosłowiańskich Instytutu Słowianoznawstwa PAN (obecnego Instytutu Slawistyki PAN). Zespół w składzie Kazimierz Feleszko, Violetta Koseska-Toszewa, Małgorzata Korytkowska, Jolanta Mindak i Irena Sawicka opracował nowatorski projekt opisu konfrontatywnego na potrzeby dwóch gramatyk: bułgarsko-polskiej i serbskochorwacko-polskiej (por. „Projekt”, 1984). Był to pierwszy w świecie projekt budowy semantycznej gramatyki konfrontatywnej opartej na logice i semantyce. Ekspertami tegoż projektu w różnych okresach byli wybitni polscy i bułgarscy językoznawcy: Swetomir Iwanczew, Ruselina Nikołowa, Jordan Penczew, Dina Staniszewa, Kazimierz Feleszko, Stanisław Karolak, Roman Laskowski, Kazimierz Polański i Janusz Siatkowski. $\mathrm{Na}$ Gramatykę składają się monografie na następujące tematy:

1. Fonetyka i fonologia (Савицка, \& Бояджиев, 1988);

2. Semantyczna kategoria określoności/nieokreśloności (Косеска-Тошева \& Гаргов, 1990);

3. Semantyczna kategoria ilości (Крумова-Цветкова \& Рошко, 1994);

4. Semantyczna kategoria stopnia (Петрова-Вашилевич \& Чоролеева, 1994);

5. Typy pozycji predykatowo-argumentowych (Korytkowska, 1992);

6. Semantyczna kategoria komunikanta (Гугуланова, Шимански, \& Баракова, 1993);

7. Modalność - teoria opisu (Koseska-Toszewa, Maldžieva, \& Penčev, 1995);

8. Semantyczna kategoria modalności imperceptywnej (Korytkowska \& Roszko, 1997);

9. Semantyczna kategoria modalności hipotetycznej, irrealnej, optatywnej i imperatywnej (Maldžieva, 2003);

10. Semantyczna kategoria modalności interogatywnej (Korytkowska, 2004);

11. Semantyczna kategoria czasu (Koseska-Toszewa, 2006);

12. Semantyczna kategoria aspektu (Karolak, 2008);

13. Słowotwórstwo (Maldjieva, 2009).

Profesor Koseska wniosła do językoznawstwa konfrontatywnego powiew świeżości i naukowego obiektywizmu. Starała się w sposób uporządkowany, spójny

${ }^{5}$ Na tom 6. Gramatyki składają się 4 obszerne monografie. Tom 3. Gramatyki zawiera 2 części. 
i logiczny zestawiać wiele języków. Podstawy takiej analizy wyłożyła w podejściu, które znane jest jako teoretyczne badania konfrontatywne z semantycznym językiem-pośrednikiem. Profesor odrzucała badania ukierunkowane od języka wyjściowego do docelowego. W zamian zaproponowała konstrukcję wewnętrznie spójnego języka pojęć (czyli języka-pośrednika), z którym na dalszych etapach prac był zestawiany każdy język zestawienia. Profesor Violetta Koseska zawsze podkreślała, że język-pośrednik to nie język opisu (metajęzyk).

Kolejnym wielkim dziełem profesor Koseskiej była teoria kwantyfikacji zakresowej - czyli sformalizowany opis zjawisk określoności i nieokreśloności na poziomie zdania z wykorzystaniem jednoznacznych w interpretacji kwantyfikatorów i operatorów logicznych. W pracach nad określonością/nieokreślonością w językach polskim i bułgarskim wprowadziła pojęcia silnych i słabych znaczeń kwantyfikacyjnych $\mathrm{w}$ powiązaniu $\mathrm{z}$ zasięgami oddziaływania i wzajemnego zawierania się kwantyfikatorów, a także wyróżniła znaczenia niedopowiedzenia kwantyfikacyjnego (szczególnie charakterystycznego w polszczyźnie) i czystej predykacji.

Zastosowanie teorii sieci Petriego w implementacji opracowanej przez profesora Antoniego Mazurkiewicza do opisu języka naturalnego było kolejną przełomową, konsekwentnie stosowaną przez Profesor w językoznawstwie metodą analizy i opisu czasu, aspektu oraz modalności. Rozróżnienie oraz wzajemna konfiguracja stanów i zdarzeń oraz ciągów stanów i zdarzeń zakończonych albo stanem, albo zdarzeniem pozwala interpretować różne wartości aspektualne. Natomiast samo odniesienie do stanu wypowiedzi definiuje podstawowe jednostki czasu, takie jak czas teraźniejszy, czas przeszły, czas przyszły i czas ogólny. Z kolei rozwidlenia i rozgałęzienia pozwalają interpretować poszczególne wartości modalne.

Profesor Koseska wprowadziła nowe rozumienie gramatyki, łączące w sobie tradycyjnie pojmowaną gramatykę i leksykę. Nowa gramatyka bazuje nie na kategoriach morfologicznych, lecz na uniwersalnych kategoriach semantycznych, których wykładnikami są środki leksykalne, morfologiczne i syntaktyczne oraz ich wszelkie kombinacje.

Śp. Profesor Violetta Koseska była osobą pogodną, otwartą, hojną i gościnną. Bezgranicznie oddaną rodzinie i nauce. Lubiła, jak to zodiakalny strzelec, dużo mówić i (nieco mniej) jeść. Jako typowa Bułgarka uwielbiała chleb. Mówiła często, ale potrafiła też słuchać. Prowadziła intelektualne rozmowy. Poruszała 
trudne tematy. Szanowała autorytety i uznawała tradycje. Była osobą stanowczą, dobrze znającą swoją wartość i swoje miejsce. Potrafiła z gorliwością bronić nawet nieznane sobie osoby, gdy były niesłusznie atakowane. Nigdy nie udawała, że coś wie, że o czymś słyszała, jeśli było to nieprawdą. Potrafiła powiedzieć, że na czymś się nie zna. Niech każdy robi to, co potrafi najlepiej - powtarzała. Skutecznie mobilizowała ludzi do pracy - gdy przybywała w sprawach naukowych do Sofii, na twarzach wielu bułgarskich kolegów pojawiało się przerażenie. Profesor Koseska bardzo lubiła psy i koty, dokarmiała ptaki. Dbała o otoczenie domu. Sadziła krzewy i drzewa, zawieszała karmniki. A bułgarskie róże pięły się po ścianach i płotach. Ich kojący zapach witał częstych w domu profesorskim gości z całego świata.

Śp. Profesor Violetta Koseska jest i pozostanie w naszej pamięci na zawsze, a jej prace i teorie będą inspirować nowe pokolenia językoznawców.

Wdzięczny za lata twórczej współpracy Roman Roszko

\section{Bibliografia}

CLARIN-PL. (b.d.). Pobrano z http://ispan.waw.pl/default/pl/projekty-naukowe/215-clarin

Karolak, S. (2008). Gramatyka konfrontatywna bułgarsko-polska: T. 8. Semantyczna kategoria aspektu. Warszawa: Instytut Slawistyki PAN.

Kisiel, A., Koseska-Toszewa, V., Kotsyba, N., Satoła-Staśkowiak, N., \& Sosnowski, W. (2016). PolishBulgarian-Russian Parallel Corpus. Pobrano z https://clarin-pl.eu/dspace/handle/11321/308

Korytkowska, M. (1992). Gramatyka konfrontatywna bułgarsko-polska: T. 5. Typy pozycji predykatowo-argumentowych. Warszawa: Instytut Slawistyki PAN.

Korytkowska, M. (2004). Gramatyka konfrontatywna bułgarsko-polska: T. 6/4. Modalność interrogatywna. Warszawa: Instytut Slawistyki PAN.

Korytkowska, M., \& Roszko, R. (1997). Gramatyka konfrontatywna bułgarsko-polska: T. 6/2. Modalność imperceptywna. Warszawa: Instytut Slawistyki PAN.

Koseska-Toszewa, V. (2006). Gramatyka konfrontatywna bułgarsko-polska: T. 7. Semantyczna kategoria czasu. Warszawa: Instytut Slawistyki PAN.

Koseska-Toszewa, V., Maldžieva, V., \& Penčev, J. (1995). Gramatyka konfrontatywna bułgarsko-polska: T. 6/1. Modalność: Teoretyczne problemy opisu. Warszawa: Instytut Slawistyki PAN.

Koseska-Toszewa, V., \& Roszko, R. (2015). On semantic annotation in CLARIN-PL parallel corpora. Cognitive Studies / Études cognitives, 2015(15), 211-236. https://doi.org/10.11649 /cs.2015.016 
Koseska-Toszewa, V., \& Roszko, R. (2016). Języki słowiańskie i litewski w korpusach równoległych CLARIN-PL. Studia z Filologii Polskiej i Słowiańskiej, 2016(51), 191-217. https://doi.org /10.11649/sfps.2016.011

Lebedys, J. (1977). Senoji lietuviu literatūra. Vilnius: Mokslas.

Maldjieva, V. (2009). Gramatyka konfrontatywna bułgarsko-polska: T. 9. Semantyczna kategoria czasu. Warszawa: Instytut Slawistyki PAN.

Maldžieva, V. (2003). Gramatyka konfrontatywna bułgarsko-polska: T. 6/3. Modalność: hipotetyczność, irrealność, optatywność i imperatywność, warunkowość. Warszawa: Instytut Slawistyki PAN.

Projekt gramatyki konfrontatywnej bułgarsko-polskiej i serbskochorwacko-polskiej: Wstęp. (1984). In K. Polański (Red.), Studia polsko-południowosłowiańskie. Wrocław: Zakład Narodowy im. Ossolińskich.

Roszko, D., \& Roszko, R. (2016). Polish-Lithuanian Parallel Corpus. Pobrano z https://clarin-pl .eu/dspace/handle/11321/309

Roszko, R., \& Roszko, D. (2018). Polish-Lithuanian Parallel Corpus “2”. Pobrano z https:// clarin-pl.eu/dspace/handle/11321/539

Гугуланова, И., Шимански, М., \& Баракова, П. (1993). Българско-полска съпоставителна граматика: T. 4. Семантичната категория комуникант. София: Издателство на БАН.

Косеска-Тошева, В., \& Гаргов, Г. (1990). Българско-полска съпоставителна граматика: Т. 2. Семантичната категория определеност/неопределеност. София: Издателство на БАН.

Крумова-Цветкова, Л., \& Рошко, Р. (1994). Българско-полска съпоставителна граматика: T. 3/1. Семантичната категория количество. София: Издателство на БАН.

Петрова-Вашилевич, А., \& Чоролеева, М. (1994). Българско-полска съпоставителна граматика: T. 3/2. Семантичната категория степен. София: Издателство на БАН.

Савицка, И., \& Бояджиев, Т. (1988). Българско-полска съпоставителна граматика: Т. 1. Фонетика и фонология. София: Издателство на БАН.

\section{Bibliography (Transliteration)}

CLARIN-PL. (n.d.). Retrieved from http://ispan.waw.pl/default/pl/projekty-naukowe/215-clarin

Gugulanova, I., Shimanski, M., \& Barakova, P. (1993). Bŭlgarsko-polska sŭpostavitelna gramatika: Vol. 4. Semantichnata kategoriia komunikant. Sofiia: Izdatelstvo na BAN.

Karolak, S. (2008). Gramatyka konfrontatywna bułgarsko-polska: Vol. 8. Semantyczna kategoria aspektu. Warszawa: Instytut Slawistyki PAN.

Kisiel, A., Koseska-Toszewa, V., Kotsyba, N., Satoła-Staśkowiak, N., \& Sosnowski, W. (2016). Polish-Bulgarian-Russian Parallel Corpus. Retrieved from https://clarin-pl.eu /dspace/handle/11321/308 
Korytkowska, M. (1992). Gramatyka konfrontatywna bułgarsko-polska: Vol. 5. Typy pozycji predykatowo-argumentowych. Warszawa: Instytut Slawistyki PAN.

Korytkowska, M. (2004). Gramatyka konfrontatywna bułgarsko-polska: Vol. 6/4. Modalność interrogatywna. Warszawa: Instytut Slawistyki PAN.

Korytkowska, M., \& Roszko, R. (1997). Gramatyka konfrontatywna bułgarsko-polska: Vol. 6/2. Modalność imperceptywna. Warszawa: Instytut Slawistyki PAN.

Koseska-Tosheva, V., \& Gargov, G. (1990). Bŭlgarsko-polska sŭpostavitelna gramatika: Vol. 2. Semantichnata kategoriia opredelenost/neopredelenost. Sofiia: Izdatelstvo na BAN.

Koseska-Toszewa, V. (2006). Gramatyka konfrontatywna bułgarsko-polska: Vol. 7. Semantyczna kategoria czasu. Warszawa: Instytut Slawistyki PAN.

Koseska-Toszewa, V., Maldžieva, V., \& Penčev, J. (1995). Gramatyka konfrontatywna bułgarskopolska: Vol. 6/1. Modalność: Teoretyczne problemy opisu. Warszawa: Instytut Slawistyki PAN.

Koseska-Toszewa, V., \& Roszko, R. (2015). On semantic annotation in CLARIN-PL parallel corpora. Cognitive Studies / Études cognitives, 2015(15), 211-236. https://doi.org/10.11649 /cs.2015.016

Koseska-Toszewa, V., \& Roszko, R. (2016). Języki słowiańskie i litewski w korpusach równoległych CLARIN-PL. Studia z Filologii Polskiej i Słowiańskiej, 2016(51), 191-217. https://doi.org /10.11649/sfps.2016.011

Krumova-Tsvetkova, L., \& Roshko, R. (1994). Bŭlgarsko-polska sŭpostavitelna gramatika: Vol. 3/1. Semantichnata kategoriia kolichestvo. Sofiia: Izdatelstvo na BAN.

Lebedys, J. (1977). Senoji lietuviu literatūra. Vilnius: Mokslas.

Maldjieva, V. (2009). Gramatyka konfrontatywna bułgarsko-polska: Vol. 9. Semantyczna kategoria czasu. Warszawa: Instytut Slawistyki PAN.

Maldžieva, V. (2003). Gramatyka konfrontatywna bułgarsko-polska: Vol. 6/3. Modalność: hipotetyczność, irrealność, optatywność i imperatywność, warunkowość. Warszawa: Instytut Slawistyki PAN.

Petrova-Vashilevich, A., \& Choroleeva, M. (1994). Bŭlgarsko-polska sŭpostavitelna gramatika: Vol. 3/2. Semantichnata kategoriia stepen. Sofiia: Izdatelstvo na BAN.

Projekt gramatyki konfrontatywnej bułgarsko-polskiej i serbskochorwacko-polskiej: Wstęp. (1984). In K. Polański (Ed.), Studia polsko-południowosłowiańskie. Wrocław: Zakład Narodowy im. Ossolińskich.

Roszko, D., \& Roszko, R. (2016). Polish-Lithuanian Parallel Corpus. Retrieved from https:// clarin-pl.eu/dspace/handle/11321/309

Roszko, R., \& Roszko, D. (2018). Polish-Lithuanian Parallel Corpus “2”. Retrieved from https:// clarin-pl.eu/dspace/handle/11321/539

Savitska, I., \& Boiadzhiev, T. (1988). Bŭlgarsko-polska sŭpostavitelna gramatika: Vol. 1. Fonetika i fonologiia. Sofiia: Izdatelstvo na BAN. 


\section{To the memory of Professor Violetta Koseska}

\section{Summary}

This paper is devoted to an outstanding scholar. Violetta Koseska was a professor of synchronic linguistics and the author and co-author of many major theories in contrastive analysis. One only needs to mention theoretical contrastive analysis with mediating semantic language, which plays a key role in equivalent simultaneous description of multiple languages, or descriptions of semantic categories of: time (using Petri net theory) and definiteness/indefiniteness (using quantifier calculus), among other things - to realize the significance of Professor Koseska's work.

\section{Pamięci Profesor Violetty Koseskiej}

\section{Streszczenie}

Tekst poświęcony wybitnej uczonej - profesor językoznawstwa synchronicznego Violetcie Koseskiej, autorce i współautorce wielu ważnych teorii z zakresu badań konfrontatywnych. Wystarczy wymienić kluczowe dla jednoczesnego równorzędnego opisu wielu języków teoretyczne badania konfrontatywne z semantycznym językiem-pośrednikiem, a także opisy kategorii semantycznych: czasu (z wykorzystaniem teorii sieci Petriego), określoności/ nieokreśloności (bazujący na rachunku kwantyfikatorów) i in., by zrozumieć i uświadomić sobie doniosłość prac zmarłej Profesor.

Keywords: Violetta Koseska-Toszewa; linguistics; theoretical contrastive analysis with mediating semantic language; semantic categories

Słowa kluczowe: Violetta Koseska-Toszewa; językoznawstwo; teoretyczne badania konfrontatywne z językiem-pośrednikiem; kategorie semantyczne

\footnotetext{
Roman Roszko, Institute of Slavic Studies, Polish Academy of Sciences, Warsaw

Correspondence: roman.roszko@ispan.waw.pl

This article was financed by the Ministry of Science and Higher Education, Republic of Poland.

Competing interests: The author has declared he has no competing interests.
} 